\title{
Toward a New Social Contract? The Participation of Civil Society in Swedish Welfare Policymaking, 1958-2012
}

\author{
Erik Lundberg ${ }^{1,2}$
}

Published online: 13 November 2017

(C) The Author(s) 2018. This article is published with open access at Springerlink.com

\begin{abstract}
In contribution to current debates on the changing roles and responsibilities of civil society in welfare state arrangements, I examined the participation of various types of civil society organizations in national welfare policymaking in Sweden between 1958 and 2012. Drawing upon an extensive dataset of over 1400 civil society, state, and for-profit organizations, I tested three claims related to the role and responsibility of civil society in the governance of welfare: the changing balance between corporatist and welfare organizations, the shift from voice to service, and another shift from nonprofit organizations to FPOs. My results revealed weak but emerging trends aligned with changing patterns of corporatism and the marketization of Sweden's welfare system. However, support for any shift from voice to service remains uncertain.
\end{abstract}

Keywords Civil society $\cdot$ Sweden $\cdot$ Welfare state $\cdot$ Social contract $\cdot$ Nonprofit organizations $\cdot$ For-profit organizations

Résumé Dans le cadre des débats actuels sur les changements que subissent les rôles et les responsabilités de la société civile dans les affaires afférentes à l'État providence, je me penche sur l'implication de divers types d'organisations de société civile dans le processus d'élaboration des politiques sociales nationales de la Suède de 1958 à 2012. À l'aide d'un imposant ensemble de données concernant plus de 1400 organisations de société civile,

Erik Lundberg

erik.lundbergs@gmail.com

1 Ersta Sköndal Bräcke University College, Stockholm, Sweden

2 Knut Stangenbergs väg 5, 13147 Nacka, Sweden
d'État et sans but lucratif, j'ai testé trois déclarations relatives au rôle et à la responsabilité de la société civile dans la gouvernance de l'assistance sociale: l'équilibre changeant entre le corporatisme et les organismes d'assistance sociale, la transition de la prise de parole à l'offre de service, et la transition d'organisme sans but lucratif à organisme à but lucratif. Mes résultats démontrent que des tendances subtiles émergent et qu'elles sont alignées sur les modèles changeants du corporatisme et de la marchéisation du système d'assistance sociale. Rien ne soutient cependant avec certitude la transition de la prise de parole à l'offre de service.

Zusammenfassung Um zu den aktuellen Debatten über die sich ändernden Rollen und Verantwortlichkeiten der Bürgergesellschaft in sozialstaatlichen Systemen beizutragen, untersuchte ich die Partizipation unterschiedlicher Arten von Bürgergesellschaftsorganisationen an Entscheidungen zur nationalen Sozialpolitik in Schweden zwischen 1958 und 2012. Dazu stützte ich mich auf einen umfassenden Datensatz von über 1400 Bürgergesellschafts-, staatlichen und gewinnorientierten Organisationen und testete drei Behauptungen hinsichtlich der Rolle und Verantwortung der Bürgergesellschaft bei der Steuerung sozialer Belange: das sich ändernde Gleichgewicht zwischen korporatistischen und Wohlfahrtsorganisationen, der Wandel von Vertreter zu Dienstleistungsanbieter und ein weiterer Wandel von gemeinnützigen Organisationen hin $\mathrm{zu}$ gewinnorientierten Organisationen. Meine Ergebnisse offenbarten zwar schwache, doch neue Trends, die mit den sich ändernden Mustern des Korporatismus und der Vermarktlichung von Schwedens Sozialsystem in Einklang liegen. Allerdings gibt es weiterhin keine sicheren Beweise für einen Wandel von Vertreter zu Dienstleistungsanbieter. 
Resumen Como contribución a los debates actuales sobre los cambiantes papeles y responsabilidades de la sociedad civil en los acuerdos del estado de bienestar, he examinado la participación de varios tipos de organizaciones de la sociedad civil en las políticas nacionales de bienestar en Suecia entre 1958-2012. Recurriendo a un extenso conjunto de datos de más de 1400 organizaciones de la sociedad civil, estatales y con ánimo de lucro, he probado tres reivindicaciones relacionadas con el papel y la responsabilidad de la sociedad civil en la gobernanza del bienestar: el cambiante equilibrio entre organizaciones corporativistas y de bienestar, el cambio desde la denuncia al servicio y otro cambio desde organizaciones sin ánimo de lucro a organizaciones con ánimo de lucro. Mis resultados revelaron tendencias débiles pero emergentes junto con patrones de cambio del corporativismo y la marketización del sistema de bienestar de Suecia. Sin embargo, sigue incierto el apoyo para algún cambio desde la denuncia al servicio.

\section{Introduction}

Among extensively debated issues regarding civil society, the shifting role of civil society organizations (CSOs) in welfare state arrangements has long commanded scholarly attention (Smith-Rathgeb and Lipsky 1993; Henriksen et al. 2012). In response to economic and political changes, CSOs have been increasingly encouraged to step up their work as producers of public welfare in many Western states (Bode 2006; Hogg and Baines 2011). Indeed, given their knowledge legitimacy, and capacity to develop policy solutions to overcome the challenges of contemporary welfare states, CSOs have become vital in both policymaking and administration (Evers 2005).

In Sweden, now more than ever before, CSOs are expected to play a greater role in welfare reform. Long held as a prime example of an advanced welfare state that relies heavily on universal government welfare programs, Sweden currently hosts a welfare market and a powerful combination of public management reforms, both of which have created new conditions for civil society in the welfare state arrangement (Vamstad 2007; Anheier and Kendall 2012; Johansson et al. 2015). In response, leading scholars have heralded Sweden's new social contract as signaling a transformation of the basic principles of how countries should implement and control social services. More specifically, they have called attention to how the traditional responsibilities of civil society have come to encompass the governance of welfare policies and the provision of increasingly more public services at the expense of advocacy, all amid the rise of for-profit organizations (FPOs) at the expense of nonprofit ones (Wijkström 2012).
Scholarship on civil society has also provided a range of empirical evidence by which to gauge the magnitude of those alleged transformations. Consistent with trends reported in international literature, studies have, for example, called attention to shifts in political rhetoric, the division of labor, and governments' financial support that further entrench CSOs as welfare service producers (Wijkström and Einarsson 2006; Reuter et al. 2012; Johansson and Johansson 2012). Research has also shown that, during the last two decades, FPOs have expanded their role as service providers, which has consequently brought the transformation of Scandinavian welfare models to the fore (Blomqvist 2013; Burström 2015). Filling out that picture, a growing body of literature has underscored challenges and opportunities within civil society, including hybridization, professionalization, and the rise of both volunteerism and social entrepreneurship (Grassman and Svedberg 2007; Markström and Karlsson 2013; Hvenmark 2013; Gawell 2013).

Although scholars have paid ample attention to the role and responsibilities of civil society in the output of the political system-that is, its implementation of social welfare-they have often neglected its input in the formation of public policy. Moreover, with few exceptions (Lundberg 2012), scholars have not taken a historical perspective in examining the transformation and, consequently, remain incompletely aware of the magnitude and direction of the shifting role and responsibilities of civil society that have emerged in recent decades. Accordingly, knowledge about what characterizes actors in control of the transformation of the welfare state, who generate policy initiatives, ideas, and legitimacy in policymaking, is in short supply. In response, to understand the direction and magnitude of the transformation with respect to the role and responsibilities of civil society, empirically based historical knowledge is necessary.

With this study, I aimed to contribute to that shortcoming by analyzing the participation of civil society in the formation of Swedish welfare policymaking from 1958 to 2012. In particular, I sought to identify the extent to which Sweden's alleged new social contract has involved new roles and responsibilities for CSOs in national welfare policymaking since the second half of the twentieth century. To that end, I drew upon three claims in scholarship on CSOs and interest groups: the changing balance between corporatist and welfare organizations, the shift from voice to service, and another shift from nonprofit organizations to FPOs.

I gathered empirical evidence from unique data purporting the participation of more than 1400 CSOs, state actors, and market players in the Swedish national policymaking process. Among the various arenas in which CSOs can participate to influence policymaking, parliament, media outlets, personal contact with politicians, and public consultation with civil servants are most common in the 
preparation of public policies. In my study, I drew upon evidence from the Swedish remiss procedure, which I have conceived as a particularly institutionalized policymaking arena akin to written public consultation. The procedure has a constitutional foundation insofar as different actors receive a legally protected opportunity to be heard in the policymaking process (Regeringsformen [Constitution of Sweden], chapter 7, 2§). Accordingly, while preparing policy, various parts of the Swedish government engage consultations with CSOs, which have become institutionalized owing to the system of governmental commission's investigation, preparation, and formulation of new policies and legislation (Lundberg 2014).

I analyzed the participation of the organizations in six fields central to the Swedish welfare state: childcare, disability care, health care, high school education, immigrant integration, and elderly care. In effect, my study adds nuanced empirical knowledge about the extent to and ways in which the social contract in Sweden has been renegotiated in terms of the role and responsibilities of civil society in welfare policymaking during the last 6 dec. In so doing, I shed light on what characterizes CSOs in control of the transformation of the welfare state as producers of policy initiatives, ideas, and even the legitimacy of contemporary welfare states themselves.

From a broader perspective, my findings suggest that changes in the participation of CSOs in Sweden could also imply similar changes in political contexts with a similar welfare state model or similar trends in policy and rhetoric. Although the shifting role and responsibilities of civil society are evident in many Western countries (Henriksen et al. 2012; Anheier and Kendall 2012), in many ways Sweden stands at the fore of the transformation from universal government welfare programs to the expanding role of CSOs and market players. As such, Sweden's experiences are crucial to the overall understanding of civil society worldwide and its vitality within state-dominated welfare states.

Following this introduction, in the second section I discuss theoretical propositions for the changed social contract regarding the three mentioned claims, after which I describe my research design, data, measurements, and definitions in the third section. In the fourth section, I outline my empirical results by focusing on potential shifts between corporatist and welfare organizations, advocacy and service-oriented organizations, and nonprofit organizations and FPOs. In the fifth and final section, I discuss my conclusions.

\section{Theoretical Propositions: Three Dimensions of Change in Sweden's Social Contract}

Often associated with thinkers such as Hobbes, Locke, and Rousseau, the term social contract refers to both the basic rules for how states should be controlled and the powers of the state vis-à-vis individuals. The term moreover captures the idea of how society should be organized regarding the basic rights and obligations of citizens in terms of political representation, as well as the principles for how social services should be arranged (Tilly 1975; Kaldor 2003; Rousseau 2009). Following that understanding, social contracts often stand as a reference point in discussions of the transformation of Western welfare states and the changing role and responsibilities of civil society and markets. In their discussion of the transformation and restructuring of European welfare states, Rhodes and Mény (1998) have referred to "a new social contract," whereas Wijkström (2012) used that same phrase to describe the recent transformation of the role and responsibilities of civil society in Sweden. In any case, the idea of social contract relates to the basic principles of how social services should be controlled and implemented, as well as to the sometimes shifting role and responsibilities of civil society, states, and markets. In this article, I use social contract in reference to the reformed role and responsibilities of civil society in welfare governance.

The research that I cite comes from scholarship on interest groups and scholarship on civil society. Both strands focus on three dimensions of change in the social contract: transformations in the governance of welfare policies, the shift from voice to service, and the rise of FPOs. Drawing upon literature on interest groups, I first outline theoretical propositions for changes in the governance of welfare policy by focusing on the balance between corporatist and welfare organizations. In a second section, I build upon literature addressing civil society and provide a theoretical reference point for the shift from advocacy to service. In a third and final section, I outline a theoretical background for change concerning nonprofit and FPOs.

\section{The Shift from Corporatist Organizations to Welfare Organizations}

Regarding the governance of national welfare policymaking, researchers have often posited neocorporatism as a central point of departure (Christiansen et al. 2010; Öberg et al. 2011). Corporatism is generally understood as a system of interest representation or intermediation in democratic states in which a limited number of privileged organizations participate in policymaking (Schmitter 1979). Accordingly, researchers have typically emphasized labor unions and business interests as key players in developing various policies, often ones concerning economic issues. In particular, labor unions occupy a central position in policymaking given their large membership and ability to both control their members and gain legitimacy in 
the policymaking process, whereas business organizations, to put it simply, control production (Williamson 1989, p. 169; Molina and Rhodes 2002). A pivotal factor in that conceptualization is the assumption that either type of organization has the resources or status necessary to control the implementation of policies among their members and therefore create stability in society.

From a historical perspective, however, not corporatism, but neocorporatism is often conceived to capture the essence of the Swedish style of policymaking and the participation of civil society in the country (Rothstein and Trägårdh 2007). Indeed, Sweden has been ranked among the most neocorporatist countries worldwide (Siaroff 1999). During most of the twentieth century, major interest groups were represented on lay boards of various government agencies, which served the overall purpose of controlling the agencies, adducing the knowledge and perspective of citizens, and, in some cases, exerting formal decision-making power over the agencies. At the same time, government commissions played a critical role in policymaking, and other than state actors, CSOs constituted the largest group of actors not only on boards dominated by producer and labor interests, but also in popular movements.

However, since the 1980s, the institutionalist position of civil society in policymaking in Sweden has weakened, as it has in Denmark and Norway as well (Blom-Hansen 2000; Lindvall and Sebring 2005). In fact, the formal inclusion of CSOs on government boards and agencies was formally abolished in the early 1990s. Scholars have suggested various explanations for the decline in neocorporatism, including new modes of state governance, the increasing heterogeneity of civil society, and the unwillingness of CSOs to participate in neocorporatist institutions. In Scandinavian literature on the topic, a central argument is that representation has had to be more concurrent with pluralism (Hermansson et al. 1999; Lindvall and Sebring 2005) and that policymaking has thus assumed a more varied form due to lobbying and media.

Concerning the participation of civil society in welfare policymaking, the decline of neocorporatism might suggest that the privileged position of corporatist organizations has generally weakened, as reflected by the increased participation of CSOs in welfare policymaking (Hermansson et al. 1999; Lundberg 2014). In short, with the inclusion of more organizations in policymaking, the privileged pattern of participation has become less evident.

At the same time, corporatist patterns in policymaking may be stronger than assumed. In conceiving corporatism as a constantly evolving phenomenon, the traditional corporatist model of interest representation may have not disappeared, but instead adapted to a new political environment (Molina and Rhodes 2002). In that context, scholars have drawn attention to a potential shift in support for the welfare state from labor unions to welfare organizations. More specifically, as the need for and interest in adjusting or reducing public expenditure on welfare have grown, organizations that can evolve in relation to existing welfare programs have occupied a more privileged position in policymaking, primarily because the state needs support, legitimacy, and even human resources to adjust the welfare system (Pierson 2006). As a result, welfare organizations have been able to occupy a more privileged position, as indicated in the decreased participation of such organizations in the formation of Swedish welfare policymaking.

\section{From Voice to Service}

With the decline of institutionalized patterns of participation in welfare policymaking, scholars of civil society issues have repeatedly called attention to a potential shift in the role of CSOs from voice to service (Wijkström 2004; Amnå 2006). Once formally conceived as mediators of interests among individuals, as well as the expression and institutionalization of the value of pluralism in society, CSOs have come to assume a greater role in the output of the political system, chiefly as implementers or producers of welfare services. Interestingly, that emerging role reflects the one that CSOs played prior to the expansion of the welfare state.

First perceptible in policy and politics in the 1990s, various interrelated trends are thought to account for the changed role of CSOs. For one, as scholars have pointed out, a shift in economic support of CSOs has occurred, in which general and unrestricted grants and subsidies have been replaced with short-term contracts and commercial solutions (Johansson 2003). Another shift-one of political rhetoric-has also occurred. Although once formally acknowledged as a complement to public welfare, CSOs have increasingly become an alternative source of welfare provision, as symbolized by the introduction of compacts and partnerships as informal nonbinding agreements among states, local authorities, and CSOs in welfare provision (Morison 2000; Reuter et al. 2012).

From the perspective of policymaking, the trends have drawn attention to the democratic role of civil society. In general, democratic government depends on associations that mediate between individuals and the state, function as venues for collective action, and pressure and resist the political center (Warren 2001). However, when institutional conditions increasingly promote and support service functions, civil society, in its role of providing a voice of pressure and resistance, runs the risk of becoming marginalized (Eikenberry and Kluver 2004; Amnå 2006). 
At the same time, other observers have rejected the argument that participation in national policymaking has shifted from voice to service (Öberg and Svensson 2012), while at its height, still others confirmed indications of the trend (Lundberg 2012). It is important to bear in mind, however, that new CSOs over time may enter the arena with a goal to deliver welfare services. Furthermore, any potential shift from voice to service could not only be driven by state initiatives, but also follow from a commitment within civil society to step up its role as a welfare service provider. Yet, empirical evidence of the change remains sparse, and given the arguments above, it is possible that a shift in the role of CSOs from voice to service has taken place. With respect to welfare policymaking, such thinking could contend that organizations primarily oriented toward advocacy have declined in welfare policymaking during the second half of the twentieth century.

\section{From Nonprofit Organizations to FPOs}

Closely related to those changes, Scandinavian states in general and Sweden in particular have experienced a shift toward decentralization and privatization (Esping-Andersen 1996; Hemerijck 2013). As states suffered from fiscal crises in the 1980s and 1990s, private sector management styles known as new public management emerged to improve the efficiency, quality, and effectiveness of the public sector (Lægreid and Christensen 2013). Over time, the Swedish welfare system gradually opened to private service producers, and the state's near-monopoly disappeared. A neoliberal political agenda and the growth of heterogeneous needs and expectations among arguably more individualist citizens nurtured that development, which in turn created a demand for alternatives to statedriven welfare services (Inglehart 1997; Hemerijck 2013).

Empirical studies have indicated that, among those alternatives, FPOs have strengthened their position in the formation and implementation of public policies. A study on the participation of CSOs in national policymaking found that business organizations had increased from 14 to 22\% during 1963-2009 (Lundberg 2015, p. 320), which confirms earlier trends reported by Hermansson et al. (1999, p. 34) during 1971-1997. A similar trend is discernible in the balance of nonprofit organizations and FPOs in implementing welfare services, as revealed most readily by growth in their number of employees. Between 2002 and 2010, the share of employees in nonprofit organizations remained stable, from 4.3 to $4.5 \%$, yet in FPOs increased from 6.8 to $12.7 \%$ (Hartman 2011, p. 23; Wijkström and Einarsson 2006). Although the share of private organizations operating as welfare service providers has remained lower in Sweden than in other countries (Meijer et al. 2000), the above arguments and empirical evidence could indicate that the share of for-profit actors in welfare policymaking during the second half of the twentieth century increased.

Altogether, in this section I have provided a theoretical reference point for my empirical study by reviewing major changes in the role and responsibilities of civil society during the second half of the twentieth century. On that account, three trends are clear, all of which correspond to the recurring claims of scholars (Wijkström 2012). First, the decline of corporatism has challenged the privileged role of labor and business organizations in welfare provision. Second, changes in the government-based financial support of civil society and political rhetoric have encouraged CSOs to act as providers of welfare services at the expense of organizations known for advocacy. In parallel, the rise of the privatization and marketization of the welfare state has acted as a bellwether of FPOs in welfare provision.

\section{Research Design and Definitions}

To analyze the participation of CSOs in the formation of welfare policies, I derived data purporting the Swedish remiss procedure, in which policy proposals-that is, Statens Offentliga Utredningar (SOU) reports-are subject to written considerations from CSOs, government agencies, and market actors. Although various parts of Sweden's government use the procedure while preparing policies, the procedure has become particularly institutionalized in the final phases of governmental commissions that study, prepare, and formulate new policies and legislation. A government commission or committee can be a temporary, freestanding body of inquiry aimed at formulating political goals and preparing or amending legislation on specific policy. The system of governmental commissions represents key institutions in Swedish policymaking, one that are often associated with a neocorporative mode of governance. Although their role in policymaking appears to have changed, governmental commissions and the remiss procedure continue to be important parts of how CSOs influence and interact with the Swedish government (Lundberg 2015; Lundberg and Hysing 2016).

Compared with the Swedish governmental commissions, the remiss procedure is sometimes associated with a corporatist mode of governance (Hermansson et al. 1999), despite its more pluralist traits (Lundberg 2014). Remiss is an open process in which anyone, whether an organization or individual, may participate by sending written comments regarding policy proposals to the responsible ministry. Governmental agencies are legally required to respond to referrals, although no other actors are obliged to 
participate. Consequently, actual participation in the remiss procedure depends on personal or organizational selection. In complement to the open remiss procedure, a government selection process occurs in which the government-primarily officials at government offices-invites organizations thought to have a stake in the policy. In the dataset used for the study reported here, $51 \%$ of the written responses from CSOs were spontaneous. However, I have not differentiated solicited from spontaneous written comments in light of my aim to capture trends in the participation of CSOs across time. I therefore define participation as a written response to a commission proposal submitted, either spontaneously or in reply to an invitation from the government.

I collected data from 24 remiss lists ("Appendix") from 1958 to 2012 that include 1435 actors, of which 595 are CSOs, 787 are state actors, and 53 are FPOs. The late 1950s provides an appropriate basis for assessing what the various transformations of the Swedish welfare state imply for the participation of civil society. By analyzing the extent to which different types of CSOs have participated in the Swedish remiss procedure, I can reveal changes concerning the role and responsibilities of CSOs in welfare policymaking during the second half of the twentieth century.

The remiss lists encompass six different fields that together represent a broad palette of policy topics, including childcare, disability care, high school education, immigrant integration, and elderly care. From each field, I chose four comparable government commissions in order to facilitate longitudinal comparisons. Since the lists represent major governmental commissions covering rather extensive policy reforms and programs, I excluded commissions aimed at making minor adjustments to existing policies or at merely generating research reports. Among merits of that approach, it prevents variation solely due to type of commission, for including relatively extensive commissions with far-reaching political implications could benefit CSOs with more comprehensive agendas such as trade unions and producer interest groups.

Selecting a broad category of welfare policy fields enabled my assessment of CSOs' participation in the political process regarding Swedish welfare. My rationale for selecting policy fields sought to include a broad category of issues that pique the interest of a variety of CSOs, as well as to include policies of core areas of welfare operations. Although the selected policy fields do not encompass all aspects of the Swedish welfare system and, as such, do not constitute a representative sample, they do embrace a broad palette of policy issues that together provide a comprehensive picture of CSOs' participation in Swedish welfare policymaking.
To enable comparisons over time, I clustered the remiss lists from the 24 government commissions into four periods-1958-1979, 1980-1989, 1990-1999, and 2000-2012 — each with a list from each field of policy. I chose 1958 as the starting point for comparisons because that year marked the establishment of the oldest commission. As Appendix 1 shows, the 1960s had fewer commissions than the 1990s and 2000s, which reflects the growth of the Swedish commission system, as well as merits consideration when interpreting the results. All told, a commission from each policy field represents each period, and each commission in each field addresses comparable questions or problems.

\section{Definitions and Dimensions of Civil Society}

Needless to say, the concept of civil society is central to my analysis. During recent decades, intense discussions of the theoretical foundation and usefulness of the concept have occurred, however (Foley and Edwards 1996; Trägårdh 2007), and consequently, conceptualizations and definitions of the term show no consensus. Nevertheless, civil society often refers to the intermediate associations, movements, and interest groups, among other forces, operating between the state and market. In this paper, since I conceptualize civil society as a societal arena distinct from the state, market, and family (Cohen and Arato 1992; Foley and Edwards 1996), I follow its most well-known definition. $^{1}$

To explain variation in the role and responsibilities of CSOs, I build upon three dimensions of civil society from earlier research on the topic. To account for the first dimension, I draw upon literature addressing interest groups (Binderkrantz 2008) that has identified two categories of organizations corresponding to the overarching theoretical distinction outlined above: corporatist organizations and welfare organizations. On the one hand, corporatist organizations include trade unions such as Landsorganisationen i Sverige (Swedish Trade Union Confederation) and Lärarförbundet (Swedish Teachers' Union) and business organizations such as Svenskt Näringsliv (Swedish Trade Federation) and Teknikföretagen (Association of Swedish Engineering Industries). In the Scandinavian literature on interest groups, business organizations also include membership groups, but not individual business firms seeking political influence (Binderkrantz 2008). On the other, welfare organizations consist of professional groups, identity groups, and public

\footnotetext{
${ }^{1}$ State refers to municipal and state agencies and organizations, the judiciary, and companies that are more than half-owned by public entities, including Government Survey Support, the Legal, Financial and Administrative Services Agency, the City of Stockholm, the Office of the Parliamentary Ombudsmen, and Swedish courts.
} 
interest groups. In particular, professional organizations include organizations with members of a common profession and that work to promote professionalism and spread knowledge related to their profession. The subcategory thus includes, for example, Lärare i Samhällskunskap (Social Studies Teachers) and Sveriges Författarförbund (Swedish Writers' Union). Meanwhile, public interest groups include organizations seeking the collective good and appeal to the population at large, not only their members. Such organizations are driven by ideologically based visions for the common good and include, for example, Sveriges Konsumenter (Swedish Consumers' Association) or Riksförbundet för sexuell upplysning (Swedish Association for Sexuality Education). The category also encompasses schools operated on a nonprofit basis. Lastly, identity organizations include, for instance, Kurdiska Riksförbundet (Kurdish National Association), Filadelfiakyrkan (Philadelphia Church), and De Handikappades Riksförbund (National Association for the Disabled). In that subcategory, organizational members are united by a specific identity based upon ethnicity, religion, or physical or psychological diseases, among other things. Apart from both corporatist and welfare organizations are entities such as hobby clubs that do not fit into either category.

A second dimension of civil society differentiates advocacy-oriented organizations from service-oriented ones. Advocacy-oriented organizations generally seek to influence the policy agenda via lobbying or other means. Considered to be genuine expressions of citizens' interests and priorities, the groups compete with the state, challenge the status quo, and function as democratic infrastructure seeking the common good. The category includes organizations such as Handikappförbunden (Workers' Educational Association and the Swedish Disability Federation). By contrast, the chief goal of service-oriented organizations is to provide various services to target groups, cultivate strong local communities, solve social problems, and ensure a sense of belonging, all while working for the interests of their members and taking responsibility for the public benefit. The group includes organizations such as Demensförbundet (National Association for the Rights of the Demented) and Anhörigas Riksförbund (Carers Sweden).

Regarding the potential shift from nonprofit organizations to FPOs, the third dimension is the well-known separation of those two types of organizations. On the one hand, nonprofit organizations are noninstitutionalized to some extent and self-governing, and they do not return profits to their owners or directors. Furthermore, they are not primarily involved in promoting candidates for elected office (Anheier 2005). That characterization agrees with how scholars have typically defined civil society and extends to, for example, Lärarnas Riksförbund (National Union of Teachers in Sweden), Historielärarnas Förening (History Teachers), and Schizofreniförbundet (Schizophrenia Association). FPOs, on the other hand, refer to any organizations aiming at distributing their surplus income to the organization's shareholders (e.g., owners) as profit or by offering services to the public or specific target groups. The category includes organizations such as Carema Care AB, Attendo Care, Kunskapsskolan, Särnmark Assistans.

By using those dimensions of civil society as a point of departure, I empirically scrutinized the alleged decline of corporatist organizations, the shift from voice to service, and the participation of nonprofit organizations and FPOs.

To identify the different dimensions and subcategories of CSOs, I referred to the official purpose or goal of each organization stated on its Web site, although the most important sources were statutes of the organizations. For organizations without Web sites, I consulted secondary sources such as other studies, historical documents, reports, and Web sites of other organizations in order to identify the purpose or goal of the organizations. ${ }^{2}$ With such information, I classified each organization according to all three dimensions. A few organizations straddled several categories (e.g., both advocacy and service) and can be thought of as "hybrid organizations" (Bills 2010). My classification is not fully capable of disclosing those types of organization, which constitutes a restriction that readers need to bear in mind when interpreting the results. I systematically mitigated that restriction by studying how organizations have ranked their priorities in their respective statutes, under the assumption that the hierarchy of an organization's objectives plays a role in its identity in each category. In cases in which the statutes were insufficient to that end, I gave additional consideration to information about the activities and tasks of the organization. As such, I based organizational identity on the most significant purpose formulated by each organization.

My procedure did not consider that CSOs active across several periods could change over time. Ideally, I would have liked to control for the purpose or goal of the organizations in each period. At the same time, researchers have suggested that the basic characteristics of an organization defined at its founding are unlikely to change entirely (Hannan and Freeman 1984), and if that problem were to crop up nonetheless, then it was circumscribed, for few organizations in such a large sample would yield only minor variation in the results. Nevertheless, that restriction should be recalled when interpreting the results.

\footnotetext{
${ }^{2}$ I excluded a few cases of organizations that defy categorization, mostly due to the impossibility of interpreting their handwritten records.
} 


\section{Results}

To present the results of my empirical investigation, I begin by discussing the participation of CSOs and state actors. Thereafter, I overview findings regarding the participation of corporatist and welfare organizations, followed by that of advocacy- and service-oriented organizations. Lastly, I address results concerning the participation of nonprofit organizations and FPOs.

As Table 1 illustrates, during the first period (1958-1979), $30 \%$ (134/440) of organizations represented CSOs. However, over time, civil society decreased by $9 \%$, or by 17 organizations, whereas the state increased by $9 \%$, or by 127 organizations. The clearest change appears to have occurred between the first (1958-1979) and second (1980-1989) periods, when civil society declined from 30 to $21 \%$ and the state increased from 68 to $77 \%$. Thereafter, the relative share of civil society and state actors became stable, albeit flexible in absolute terms. The most notable change in absolute terms occurred during the third period (1990-1999), when the overall numbers of actors, both of civil society and the state, dropped from the second period's (1980-1989) 464-219 and later increased again to 555 in the final period (2000-2012).

In reviewing the general balance of civil society and state, I should acknowledge potential changes related to the three dimensions of organizations outlined earlier. As
Table 2 reveals, during the first period (1958-1979) corporatist organizations represented $11 \%$ (49/440) of the total actors in the remiss procedure, whereas welfare organizations represented $18 \%$ (81/440). Throughout the period, corporatist organizations increased by 3 percentage points (i.e., by 25 organizations), whereas welfare organizations declined by 12 percentage points \% (i.e., by 38 organizations). The clearest changes occurred between the third (1990-1999) and final periods (2000-2012), when corporatist organizations increased from 10 to $14 \%$ and welfare organizations decreased from 19 to $6 \%$. In absolute numbers, the quantity of organizations fluctuated across the total period, as the lower levels of participants during the third period can explain. Accordingly, the results indicate a slight change in the participation of those types of CSOs.

Table 2 presents some other interesting results. Among them, trade unions were the most numerous type of corporatist organization during all periods except the final one (2000-2012). Between the third (1990-1999) and final periods, business organizations increased from 2 to $7 \%$, thereby approaching the proportion of trade unions. Regarding welfare organizations, public interest groups represented the largest type of welfare organization during all periods, while professional organizations and identity groups were relatively equal in number. The results also show that all types of welfare organizations decreased,

Table 1 Participation of civil society organizations, 1958-2012 (absolute numbers in brackets)

\begin{tabular}{lccccc}
\hline & $1958-1979$ & $1980-1989$ & $1990-1999$ & $2000-2012$ & $\begin{array}{l}\text { Difference (2000-2012 } \\
\text { versus 1958-1979) }\end{array}$ \\
\hline Civil society & $30(134)$ & $21(99)$ & $21(46)$ & $21(117)$ & $-9(-17)$ \\
State & $68(300)$ & $78(364)$ & $79(173)$ & $77(427)$ & $9(127)$ \\
Market & $1(6)$ & $0(1)$ & $0(0)$ & $2(11)$ & $1(5)$ \\
$N$ & $100(440)$ & $100(464)$ & $100(219)$ & $100(555)$ & 115 \\
\hline
\end{tabular}

Table 2 Participation of corporatist and welfare organizations, 1958-2012 (absolute numbers in brackets)

\begin{tabular}{|c|c|c|c|c|c|}
\hline & 1958-1979 & $1980-1989$ & 1990-1999 & 2000-2012 & $\begin{array}{l}\text { Difference (2000-2012 } \\
\text { vs. } 1958-1979)\end{array}$ \\
\hline Corporatist organizations & $11(49)$ & $8(36)$ & $10(23)$ & $14(74)$ & $3(25)$ \\
\hline Trade unions & $6(25)$ & $6(28)$ & $8(18)$ & 7 (37) & $1(12)$ \\
\hline Business organizations & $5(24)$ & $2(8)$ & $2(5)$ & $7(37)$ & $2(13)$ \\
\hline Welfare organizations & $18(81)$ & $13(63)$ & $19(22)$ & $6(43)$ & $-12(-38)$ \\
\hline Professional organizations & $6(27)$ & $2(9)$ & $2(4)$ & $1(5)$ & $-5(-22)$ \\
\hline Public interest organizations & $9(38)$ & $8(36)$ & $6(14)$ & $5(29)$ & $-3(-9)$ \\
\hline Identity groups & $4(16)$ & $3(15)$ & $2(4)$ & $2(9)$ & $-2(-7)$ \\
\hline Other organizations & $1(4)$ & $0(0)$ & (0) (1) & $0(0)$ & $-1(-4)$ \\
\hline For-profit & $1(6)$ & $0(1)$ & $0(0)$ & $2(11)$ & $1(5)$ \\
\hline State & $68(300)$ & $78(364)$ & 79 (173) & 77 (427) & $9(127)$ \\
\hline$N$ & $100(440)$ & $100(446)$ & $100(219)$ & $100(555)$ & 115 \\
\hline
\end{tabular}


although professional organizations decreased most between the first (1959-1979) and second (1980-1989) periods, in both relative and absolute terms.

The results thus provide evidence of a slight change in the governance of welfare in Sweden. As the share of corporatist organizations declined slightly, welfare organizations boosted their participation in the remiss procedure. The clearest change between corporatist and welfare organizations occurred between the third (1990-1999) and final (2000-2012) periods. That result corresponds well with the declining trend of corporatism, in which a limited number of corporatist organizations participated in national policymaking. However, the decrease in welfare organizations raises questions concerning how the relationship between those types of organizations and the state should be understood.

Turning to the distinction between advocacy- and service-oriented organizations, Table 3 shows that advocacyoriented groups represented 29\% (126/440) of actors in the remiss procedure during the first period (1958-1979), whereas service-oriented ones represented 1\% (5/440). However, across the twentieth century, the share of advocacy-oriented organizations decreased by 10 percentage points (i.e., by 21 organizations), whereas service-oriented ones increased by only 1 percentage point (i.e., by 5 organizations). The clearest change occurred between the first (1958-1979) and second (1980-1989) periods, when advocacy-oriented organizations decreased from 29 to $20 \%$. Corresponding findings emerged among the results in absolute numbers, although the quantity of organizations fluctuated across the total period. The most visible change in service-oriented organizations occurred between the third (1990-1999) and final (2000-2012) periods, which showed a slight increase in absolute numbers.
Taken together, at a first glance the results generally support the three claims. However, the decline of advocacy-oriented organizations predates shifts in the emphasis on politics and policy in the 1990s, which could indicate that such changes did not relate to the shift from voice to service reported in the literature.

Lastly, Table 4 directs attention to the distinction between nonprofit organizations and FPOs. Results show that FPOs represented only $1 \%(6 / 440)$ of participating actors in the remiss procedure during the first period (1958-1979), whereas nonprofit organizations represented 30\% (134/440). However, over time, FPOs increased by only 1 percentage point between the first and final periods, whereas nonprofit organizations decreased by 9 percentage points. A similar shift emerged in absolute numbers; FPOs increased from 1 to 11, and nonprofit ones decreased from 134 to 117 .

Although the relative prominence of nonprofit organizations declined across the total period, the results provide scant support for claims of a stronger role of FPOs in welfare policymaking. However, the increasing role played by business organizations merits close attention. As Table 2 indicates, business organizations increased from 2 to $7 \%$ between the third and final periods. Since such organizations represent individual FPOs organized as nonprofit organizations, the results suggest an increase in FPOs' collective mobilization in welfare policymaking. Altogether, that finding generates some support for claims of a stronger role of FPOs in welfare policymaking.

In sum, the results demonstrate that CSOs represented about a third of all actors in welfare policymaking during the total period. Over time, CSOs decreased in relative number, whereas the state strengthened its position. Furthermore, the results show that corporatist organizations

Table 3 Participation of advocacy- and service-oriented organizations, 1958-2012 (absolute numbers in brackets)

\begin{tabular}{|c|c|c|c|c|c|}
\hline & 1958-1979 & 1980-1989 & 1990-1999 & 2000-2012 & $\begin{array}{l}\text { Difference (2000-2012 } \\
\text { vs. 1958-1979) }\end{array}$ \\
\hline Advocacy & 29 (126) & $20(94)$ & $19(42)$ & $19(105)$ & $-10(-21)$ \\
\hline Service & $1(5)$ & $1(5)$ & $2(4)$ & $2(10)$ & $1(5)$ \\
\hline Other organizations & $1(3)$ & $0(0)$ & $0(0)$ & $0(2)$ & $(-1)(-1)$ \\
\hline For-profit & $1(6)$ & $0(1)$ & $0(0)$ & $2(11)$ & $1(5)$ \\
\hline State & $68(300)$ & 78 (364) & 79 (173) & 77 (427) & $9(127)$ \\
\hline$N$ & $100(440)$ & $100(464)$ & $100(219)$ & $100(555)$ & (115) \\
\hline
\end{tabular}

Table 4 Participation of nonprofit and for-profit organizations, 1958-2012 (absolute numbers in brackets)

\begin{tabular}{lccccl}
\hline & $1958-1979$ & $1980-1989$ & $1990-1999$ & $2000-2012$ & $\begin{array}{l}\text { Difference (2000-2012 } \\
\text { vs. 1958-1979) }\end{array}$ \\
\hline Nonprofit & $30(134)$ & $21(99)$ & $21(46)$ & $21(117)$ & $-9(-17)$ \\
For-profit & $1(6)$ & $0(1)$ & $0(0)$ & $2(11)$ & $1(5)$ \\
State & $68(300)$ & $78(364)$ & $79(173)$ & $77(427)$ & $9(127)$ \\
$N$ & $100(440)$ & $100(464)$ & $100(219)$ & $100(555)$ & 115 \\
\hline
\end{tabular}


increased slightly in proportion, whereas welfare organizations declined between the third and final periods. That outcome implies a relative weaker role of advocacy-oriented organizations in welfare policymaking, whereas the share of service-oriented organizations remained marginal and relatively stable. Lastly, the share of nonprofit organizations declined, whereas that of FPOs remained relatively stable. Nonetheless, an increase in business organizations suggests that FPOs increasingly mobilized collectively in welfare policymaking.

\section{Discussion and Conclusions}

By tracking hundreds of CSOs across time, I have examined historical trends in the participation of CSOs in Swedish welfare policymaking. Central to my study was scrutiny of an alleged transformation in the role and responsibilities of civil society in the welfare state arrangement-a so-called new social contract—involving changes in the governance of welfare policies and a more profound role of CSOs as public service providers, at the expense of advocacy, all amid a rise of FPOs at the expense of nonprofit ones (Wijkström 2012). By analyzing the participation of 1435 actors, of which 595 were CSOs, 787 were state actors, and 53 were FPOs, in six fields of welfare policy during 1958-2012 and distinguishing three dimensions of the organizations, I produced results speaking both for and against those claims.

By focusing on the Swedish consultation process-the remiss procedure-I have generated results showing that corporatist organizations - that is, trade unions and business organizations-increased slightly in relative terms, whereas welfare organizations decreased. Furthermore, I found that the share of organizations geared toward advocacy declined, whereas service-oriented organizations remained stable. Lastly, my results highlight that the share of nonprofit organizations decreased, whereas the participation of FPOs remained stable. However, an increase in business organizations indicates that FPOs made gradually more collective efforts, which provides some support for the slightly stronger role of FPOs in welfare policymaking.

The results therefore indicate that broad changes in the role and responsibilities of civil society in the welfare state arrangement regarding the output of the political system (Brandsen and Pestoff 2006; Wijkström 2012) have corollaries in the input as well. However, political incentives stressing the involvement civil society in welfare policymaking cannot be confirmed, since the state slightly strengthened its position in relation to civil society. At the same time, the overall changes were not dramatic. Rather than radical variations, the results reveal a slow process of change in the participation of CSOs in the governance of welfare, at least as shown by the Swedish remiss procedure.

My findings pose some theoretical consequences for research on the participation of civil society in welfare policymaking. First, the slight increased participation of corporatist organizations runs parallel to claims of a declining privileged pattern of corporatist organizations in Swedish policymaking (Lindvall and Sebring 2005). With the inclusion of more corporatist organizations in policymaking, the privileged pattern of participation, which marks the essence of classic corporatism, has become less evident. At the same time, the relative decrease in the participation of welfare organizations could indicate that a privileged pattern of participation may persist. Thus, instead of its total erosion, the results may reflect the emergence of a new modern form of corporatism involving contemporary political issues and new corporatized actors (Molina and Rhodes 2002, p. 309). The broader question is what the changing pattern of participation entails for political influence. Although that question cannot be addressed in detail given the scope of this paper, the increased participation of corporatist organizations could indicate that corporatist organizations have strengthened their position in Swedish national policymaking.

Furthermore, the slightly strengthened position of business organizations together with the slightly increased participation of FPOs relative to nonprofit organizations runs parallel to the gradual marketization of Sweden's welfare system (Wijkström and Einarsson 2006; Petersen and Hjelmar 2014) and those of other Western countries (Henriksen et al. 2016). The crux of my findings is the changing balance within the corporatist category-that is, between trade unions and business organizations. Between the third and final periods, business organizations appear to have strengthened their role as suppliers of knowledge, legitimacy, and policy initiatives in national welfare policymaking in Sweden. The increased participation of business organizations has coincided with a change in the political power dynamics in Swedish national politics. In 2006, Socialdemokraterna (Swedish social democratic party), which is friendlier to trade unions, was replaced a Centre-Conservative Coalition, commonly known as the Alliance, which has traditionally oriented itself toward businesses. Following that shift, various regulations upholding the neoliberal model of market-based regulation were prepared for consultation, including the law of freedom of choice that granted citizens the right to choose welfare providers, as well as more generous refinements of private organizations in, for example, the Swedish public school system. Thus, the results reveal the potential importance of ideology for understanding the participation of CSOs in national welfare policymaking in Sweden (Kendall 2010; Johansson et al. 2015). 
Lastly, in line with the hypothesis of a shift from voice to service, results indicate that organizations geared toward advocacy have declined slightly in their participation, whereas service-oriented organizations have remained stable. However, the relative decline of the participation of advocacy-oriented organizations predated changes in Swedish politics and policy, which could indicate that the changes did not relate to claims made by scholars. At the same time, the results could bear democratic implications, since organizations with the primary aim of lobbying or otherwise influencing the policy agenda and challenging the status quo have dropped in number, which raises questions about the democratic role of civil society as opponents to the state (Cohen and Arato 1992; Warren 2001). On that topic, it is important to recall that Sweden's remiss procedure is complemented by a government selection process in which the government invites organizations thought to have a stake in the policy. Thus, the reduced role of advocacy could reflect incentives by the state to lessen conflict between state and civil society. Although such trends have no empirical evidence in support, research has shown that the Swedish government has an incentive to consult insider organizations already involved in other more privileged arenas in the bureaucratic arena (Lundberg 2013). A rosier interpretation is that the results represent a mere change in priorities among civil society toward other, perhaps more collective influences upon strategies and policymaking. It is also important to remember that changes in interest representation during the 1990s could reflect a more pluralist representation that is less dependent on institutionalized arenas for policymaking such as the remiss procedure and that has thus assumed a more varied form due to lobbying and media.

At the same time, my study poses some limitations. For one, it captured only general patterns of participation, meaning that more in-depth analyses are clearly needed to capture the way in which CSOs mobilize and advocatefor example, by studying how individual organizations mobilize collectively over time, scrutinizing the claims and viewpoints raised in consultation, or examining how individual organizations have negotiated a potential balance between advocacy- and service-oriented aims and work. On that point, the set of differences between policy issues and arenas is potentially problematic. Although the remiss procedure is an important arena for welfare policymaking, differences between other arenas and institutions are possible. A second limitation is that the three dimensions of CSOs are too weak to capture the complex structures and often heterogeneous aims and means of many organizations. In response, more sophisticated analyses of different aspects of organizations are needed. Lastly, I did not control for how individual organizations change over time, meaning that future research should account for changes within organizations over time, as well as the fact that organizations might have various goals and intentions from period to period.

That said, the study also has several strengths. First, by adopting a historical perspective covering an extensive period, I have examined changes related to the role and responsibilities of CSOs in one of the world's most advanced welfare states, which has demonstrated major changes in the welfare market and a powerful combination of public management reforms. Second, by directing attention to the formation of welfare policymaking, the results of the study are vital to a clearer understanding of the direction and magnitude of the transformation of actors in control of transforming the welfare state, who generate policy initiatives, ideas, and legitimacy in policymaking, as well as of the role and responsibilities of civil society in the formation of welfare policymaking. On that point, experiences from Sweden are crucial to the overall understanding of civil society and its vitality in government-dominated welfare states.

\section{Compliance with Ethical Standards}

Conflict of interest Author declares that he has no conflict of interest.

Open Access This article is distributed under the terms of the Creative Commons Attribution 4.0 International License (http://crea tivecommons.org/licenses/by/4.0/), which permits unrestricted use, distribution, and reproduction in any medium, provided you give appropriate credit to the original author(s) and the source, provide a link to the Creative Commons license, and indicate if changes were made.

\section{Appendix: Remiss Lists from the Following Government Commissions have been Studied}

\section{Child Care Policy}

SOU 1972:26/27 "Förskolan, betänkande avgivet av 1969 års barnstugeutredning, del 1 and 2" (Socialdepartementet)

SOU 1985:22 "Förskola—skola: betänkande av Förskola-skola-kommittén" (Utbildningsdepartementet)

SOU 1990:80 "Förskola för alla barn 1991-hur blir det?: betänkande av Aktionsgruppen för barnomsorg" (Socialdepartementet)

SOU 2008:122 Mer om fristående skolor och enskild förskoleverksamhet: slutbetänkande av Utredningen om villkoren för fristående skolor (Not: SOU 2008:8, delbetänkande om bidrag) (Utbildningsdepartementet) 


\section{Disability Care Policy}

SOU 1970:64, "Bättre socialtjänst för handikappade: förslag från Handikapputredningen om bättre färdmöjligheter för handikappade och bättre samordning $\mathrm{i}$ handikappfrågor"

SOU 1981:26 "Omsorger om vissa handikappade: betänkande av Omsorgskommittén", (Socialdepartementet)

SOU 1991:46 "Handikapp, välfärd, rättvisa, betänkande av 1989 års Handikapputredning" (Socialdepartementet) (mer om assistans i denna utredning)

SOU 2008:77 "Möjlighet att leva som andra: ny lag om stöd och service till vissa personer med funktionsnedsättning: slutbetänkande”. (Socialdepartementet)

\section{High School Policy}

SOU 1963:41-43 1960 års gymnasieutredning

(Ecklesiastikdepartementet)

SOU 1981: 96 En reformerad gymnasieskola: betänkande av 1976 års gymnasieutredning (Utbildningsdepartementet)

SOU 1997:107 Den nya gymnasieskolan problem och möjligheter. Kommittén för gymnasieskolans utveckling (Utbildningsdepartementet)

SOU 2008:27 "Framtidsvägen—en reformerad gymnasieskola. Betänkande av gymnasieutredningen" (Utbildningsdepartementet)

\section{Integration Policy}

SOU 1974:69 "Invandrarutredningen"

SOU 1984:58 "Invandrar- och minoritetspolitiken, slutbetänkande av Invandrarpolitiska kommittén",

SOU 1996:55 "Sverige, framtiden och mångfalden: slutbetänkande från Invandrarpolitiska kommittén"

SOU 2008:58 "Egenansvar med professionellt stöd".

\section{Health Care Policy}

SOU 1958:15 "Hälsovård och öppen sjukvård i landstingsområdena"

SOU 1979:78, "Mål och medel för hälso- och sjukvården: förslag till hälso- och sjukvårdslag: betänkande av Hälso- och sjukvårdsutredningen; HSU" (Socialdepartementet)

SOU 1999:66 "God vård på lika villkor?: om statens styrning av hälso- och sjukvården: slutbetänkande från Kommittén om hälso- och sjukvårdens finansiering och organisation-[HSU 2000]" (Socialdepartementet)

SOU 2008:15 "LOV att välja-Lag Om Valfrihetssystem" (Socialdepartementet)

\section{Geriatric Care Policy}

SOU 1966:45 "Aktiv åldringsvård och handikappvård: Socialpolitiska kommitténs slutliga ståndpunkt" (Socialdepartementet) SOU 1987:21 “Äldreomsorg i utveckling: slutbetänkande av Äldreberedningen” (Socialdepartementet) SOU 1997:170 "Bemötandet av äldre: slutbetänkande av Utredningen om bemötande av äldre" (Socialdepartementet)

SOU 2008:51 "Värdigt liv i äldreomsorgen" (Socialdepartementet)

\section{References}

Amnå, E. (2006). Still a trustworthy ally? Civil society and the transformation of Scandinavian democracy. Journal of Civil Society, 2, 1-20.

Anheier, H. K. (2005). Nonprofit organizations: Theory, management, policy. London, New York: Routledge.

Anheier, H. K., \& Kendall, J. (2012). Third sector policy at the crossroads: An international non-profit analysis (Vol. 10). London, New York: Routledge.

Bills, D. (2010). Towards a theory of hybrid organizations. In Hybrid organizations and the third sector: Challenges for practice, theory and policy. Palgrave Macmillan.

Binderkrantz, A. (2008). Different groups, different strategies: How interest groups pursue their political ambitions. Scandinavian Political Studies, 31(2), 173-200.

Blom-Hansen, J. (2000). Still corporatism in Scandinavia? A survey of recent empirical findings. Scandinavian Political Studies, 23, $157-181$.

Blomqvist, P. (2013). Citizenship, choice and social equality in welfare services. In K. Svedberg Helgesson \& U. Mörth (Eds.), The political role of corporate citizens: An interdisciplinary approach. Basingstoke: Palgrave Macmillan.

Bode, I. (2006). Disorganized welfare mixes: Voluntary agencies and new governance regimes in Western Europe. Journal of European Social Policy, 16(4), 346-359.

Bode, I., \& Brandsen, T. (2014). State-third sector partnerships: A short overview of key issues in the debate. Public Management Review, 16(8), 1055-1066.

Brandsen, T., \& Pestoff, V. (2006). Co-production, the third sector and the delivery of public services: An introduction. Public Management Review, 8(4), 493-501.

Burström, B. (2015). Sweden-Recent changes in welfare state arrangements. International Journal of Health Services, 45(1), 87-104.

Christiansen, P. M., Nørgaard, A. S., Rommetvedt, H., Svensson, T., Thesen, G., \& Öberg, P. (2010). Varieties of democracy: Interest groups and corporatist committees in Scandinavian policy making. VOLUNTAS: International Journal of Voluntary and Nonprofit Organizations, 21(1), 22-40.

Cohen, D., \& Arato, A. (1992). Civil society and political theory. Cambridge, London: The MIT Press.

Eikenberry, A. M., \& Kluver, J. D. (2004). The marketization of the nonprofit sector: Civil society at risk? Public Administration Review, 64(2), 132-140. 
Esping-Andersen, G. (1996). After the golden age? Welfare state dilemmas in a global economy. In Welfare states in transition: National adaptations in global economies (pp. 1-31).

Evers, A. (2005). Mixed welfare systems and hybrid organizations: Changes in the governance and provision of social services. International Journal of Public Administration, 28, 737-748.

Foley, M. W., \& Edwards, B. (1996). The paradox of civil society. Journal of Democracy, 7, 38-52.

Gawell, M. (2013). Social entrepreneurship: Action grounded in needs, opportunities and/or perceived necessities? VOLUNTAS: International Journal of Voluntary and Nonprofit Organizations, 24(4), 1071-1090.

Grassman, E. J., \& Svedberg, L. (2007). Civic participation in a Scandinavian welfare state: Patterns in contemporary Sweden. In L. Trägårdh (Ed.), State and civil society in northern Europe: The Swedish model reconsidered (pp. 126-164). New York: Berghahn Books.

Hannan, M. T., \& Freeman, J. (1984). Structural inertia and organizational change. American Sociological Review, 49, 149-164.

Hartman, L. (2011). 'Inledning' in Konkurrensens konsekvenser: Vad händer med svensk välfärd?. Stockholm: SNS Förlag.

Hemerijck, A. (2013). Changing welfare states. Oxford: Oxford University Press.

Henriksen, L. S., \& Bundesen, P. (2003). The moving frontier in Denmark: Voluntary-state relationships since 1850. Journal of Social Policy, 33(4), 605-625.

Henriksen, L. S., Smith, S. R., Thøgersen, M., \& Zimmer, A. (2016). On the road towards marketization? A comparative analysis of nonprofit sector involvement in social service delivery at the local level. In Local public sector reforms in times of crisis (pp. 221-236). Palgrave Macmillan.

Henriksen, L. S., Smith, S. R., \& Zimmer, A. (2012). At the eve of convergence? Transformations of social service provision in Denmark, Germany, and the United States. VOLUNTAS: International Journal of Voluntary and Nonprofit Organizations, 23(2), 458-501.

Hermansson, J., Lund, A., Svensson, T., \& Öberg, P. (1999). Avkorporativisering och lobbyism-Konturerna till en ny politisk modell? Statens offentliga utredningar (SOU 1991:121), Demokratiutredningens forskarvolym 13. Stockholm: Fakta Info Direkt.

Hogg, E., \& Baines, S. (2011). Changing responsibilities and roles of the voluntary and community sector in the welfare mix: A review. Social Policy and Society, 10(3), 341-352.

Hvenmark, J. (2013). Business as usual? On managerialization and the adoption of the balanced scorecard in a democratically governed civil society organization. Administrative Theory and Praxis, 35(2), 223-247.

Inglehart, R. (1997). Modernization and postmodernization: Cultural, economic, and political change in 43 societies (Vol. 19). Princeton, NJ: Princeton University Press.

Johansson, H., Arvidson, M., \& Johansson, S. (2015). Welfare mix as a contested terrain: Political positions on government-non-profit relations at national and local levels in a social democratic welfare state. VOLUNTAS: International Journal of Voluntary and Nonprofit Organizations, 26(5), 1601-1619.

Johansson, H., \& Johansson, M. (2012). From a 'Liberal' to a 'Social democratic' welfare state: the translation of the English Compact into a Swedish context. Nonprofit Policy Forum, 3(2).

Johansson, S. (2003). Independent movement or government subcontractor? Strategic responses of voluntary organizations to institutional processes. Financial Accountability and Management, 19, 209-224.

Kaldor, M. (2003). The idea of global civil society. International Affairs, 79(3), 583-593.
Kendall, J. (2010). Bringing ideology back in: The erosion of political innocence in English third sector policy. Journal of Political Ideologies, 15(3), 241-258.

Lægreid, P., \& Christensen, T. (Eds.). (2013). Transcending new public management: The transformation of public sector reforms. Farnham: Ashgate Publishing Ltd.

Lindvall, J., \& Sebring, J. (2005). Policy reform and the decline of corporatism in Sweden. West European Politics, 28, 1057-1074.

Lundberg, E. (2012). Changing balance: The participation and role of voluntary organisations in the Swedish policy process. Scandinavian Political Studies, 35(4), 347-371.

Lundberg, E. (2013). Does the government selection process promote or hinder pluralism? Exploring the characteristics of voluntary organizations invited to public consultations. Journal of Civil Society, 9(1), 58-77.

Lundberg, E. (2014). A pluralist state? Civil society organizations' access to the Swedish policy process 1964-2009. Dissertation, Örebro University, Örebro.

Lundberg, E. (2015). Det postkorporativa deltagandet: Intresseorganisationerna i den nationella politiken. In Lait fler forma framtiden! SOU 2015:96, Bilaga till betänkande av 2014 airs Demokratiutredning-Delaktighet och jämlikt inflytande (pp. 293-356). Kulturdepartementet: Wolters Kluwers förlag.

Markström, U., \& Karlsson, M. (2013). Towards hybridization: The roles of Swedish non-profit organizations within mental health. VOLUNTAS: International Journal of Voluntary and Nonprofit Organizations, 24(4), 917-934.

Meijer, A., Van Campen, C., \& Kerkstra, A. (2000). A comparative study of the financing, provision and quality of care in nursing homes. The approach of four European countries: Belgium, Denmark, Germany and the Netherlands. Journal of Advanced Nursing, 32(3), 554-561.

Molina, O., \& Rhodes, M. (2002). Corporatism: The past, present, and future of a concept. Annual Review of Political Science, 5, $305-332$.

Morison, J. (2000). Government-Voluntary sector compacts: Governance, governmentality, and civil society. Journal of Law and Society, 27(1), 98-132.

Öberg, P., \& Svensson, T. (2012). Civil society and deliberative democracy: Have voluntary organisations faded from national public politics? Scandinavian Political Studies, 35, 246-271.

Öberg, P., Svensson, T., Christiansen, P. M., Nørgaard, A. S., Rommetvedt, H., \& Thesen, G. (2011). Disrupted exchange and declining corporatism: Government authority and interest group capability in Scandinavia. Government and Opposition, 46(3), 365-391.

Petersen, O. H., \& Hjelmar, U. (2014). Marketization of welfare services in Scandinavia: A review of Swedish and Danish experiences. Scandinavian Journal of Public Administration, $17(4), 3-20$.

Pierson, C. (2006). Beyond the welfare state: The new political economy of welfare. Cambridge: Polity Press.

Reuter, M., Wijkström, F., \& von Essen, J. (2012). Policy tools or mirrors of politics. Government-voluntary sector compacts in the post-welfare state age. Nonprofit Policy Forum, 3(2).

Rhodes, M., \& Mény, Y. (Eds.). (1998). The future of European welfare: A new social contract?. Houndmills Basingstoke: Palgrave.

Rothstein, B., \& Trägårdh, L. (2007). The state and civil society in a historical perspective: The Swedish case. In L. Trägårdh (Ed.), State and civil society in Northern Europe. The Swedish Model reconsidered (pp. 229-253). New York: Berghahn Books.

Rousseau, J. J. (2009) [1762]. The social contract or principles of political right. http://www.constitution.org/jjr/socon.htm. Accessed January 31, 2017. 
Schmitter, P. C. (1979). Still the century of corporatism? In P. C. Schmitter \& L. Gerhard (Eds.), Trends towards corporatist intermediation (pp. 7-52). London: Sage.

Siaroff, A. (1999). Corporatism in 24 industrial democracies: Meaning and measurement. European Journal of Political Research, 36(2), 175-205.

Smith-Rathgeb, S., \& Lipsky, M. (1993). Nonprofits for hire: The welfare state in the age of contracting. Cambridge, MA: Harvard University Press.

Tilly, C. (1975). The formation of national states in Western Europe. Princeton, NJ: Princeton University Press.

Trägårdh, L. (2007). The "civil society" debate in Sweden: The welfare state challenged. In State and civil society in northern Europe: The Swedish model reconsidered (pp. 9-36). New York: Berghahn Books.
Vamstad, J. (2007). Governing welfare: The third sector and the challenges to the Swedish Welfare State (Doctoral dissertation, Mid Sweden University).

Warren, M. E. (2001). Democracy and association. Princeton: Princeton University Press.

Wijkström, F. (2004). Changing focus, changing role? In A. Zimmer \& C. Stecker (Eds.), Strategy mix for nonprofit organizations: Vehicles for social and market integration. New York: Plenum.

Wijkström, F. (2012). Civilsamhället $i$ samhällskontraktet. En antologi om vad som står på spel. Stockholm: Civil Society Press.

Wijkström, F., \& Einarsson, T. (2006). Frän nationalstat till näringsliv?: Det civila samhällets organisationsliv i förändring. Stockholm: Ekonomiska forskningsinstitutet (EFI), Handelshögskolan i Stockholm.

Williamson, P. J. (1989). Corporatism in perspective: An introductory guide to corporatist theory. London: Sage Publications. 